Aranjuez provided an opportunity of viewing the luxuriant growth produced by irrigation.

Honorary doctorates were conferred by the University of Madrid on Prof. M. Caullery, University of Paris; Dr. R. Goldschmidt, director of the KaiserWilhelm-Institut, Berlin-Dahlem; Dr. R. Jeannel, Muséum Naturelle d'Histoire, Paris; Prof. F. Silvestri, Portici, Italy ; and Mr. B. P. Uvarov, Imperial Institute of Entomology, London.

During the week preceding the meeting some of the members went on an excursion through the Picos de Europa under the guidance of Dr. F. M. de la Escalera, and after the Congress others visited southern Spain and the Canaries.
It is to the admirable organisation of the secretary. Dr. C. Bolivar y Pieltain, and his committee that the success of the recent Congress was due, and the lavish hospitality set a standard which few countries could hope to live up to, but there will remain in our memories also the courtesy and helpfulness of the people of Madrid to those who were ignorant of both customs and language.

It was decided to hold the seventh International Congress of Entomology in 1938 at Berlin under the presidency of Dr. E. Martini, and it is expected that the ninth will be held at Amsterdam in 1945 to coincide with the centenary celebrations of the Dutch Entomological Society.

\title{
Tercentenary of the University of Budapest
}

$\mathrm{T}$ HE recent celebration of the tercentenary of the Royal Hungarian Péter Pázmány University of Budapest was worthy of a people that has played a great part in the intellectual and political life of Central Europe. The Hungarian nation began its corporate life in 896 when the Magyars entered the country from the plains of southern Russia and the slopes of the Carpathian mountains. In the fourteenth century, and again in the fifteenth century, universities were founded, but they lasted only a comparatively short time and none survived more than a few years after the disastrous Turkish victory in 1526. In 1635, when the greater part of Hungary was still under Turkish rule, Péter Pázmány, Archbishop of Gran (Esztergom) and later Cardinal, Prince Primate, founded a new university at Nagyszombat; more than a hundred years later it was transferred to Buda and in 1783 to Pest. The two cities Buda and Pest were united in 1872. Since 1922 the University has been known as the Royal Hungarian Péter Pázmány University of Budapest. This leading university of Hungary has now more than 5,000 students : its success is a remarkable demonstration of the intellectual aspirations and the national spirit of a nation which was deprived by the Treaty of Versailles of the greater part of its territory.

Unfortunately no list of delegates was given to the representatives of foreign universities and academies who assisted at the celebrations, and it is therefore impossible to mention the names of the foreign delegates. The celebrations began in the evening of Wednesday, September 25 , with a reception in the Hotel Gellért. On the Thursday morning, the delegates and the university staff met in the great hall of the University and went in procession to the neighbouring University Church, where his Eminence the Cardinal Prince Primate, Dr. Jusztinian Serédi, assisted by a brother cardinal from Vienna and several bishops, celebrated Mass : Liszt's music was beautifully rendered. It was a memorable service. At the conclusion of the service the foreign delegates signed their names in a special commemorative book and, after visiting the University library where a collection of charters and old books relating to the Péter Pázmány foundation was exhibited, were entertained at luncheon in the Grand Hotel Hungaria, where several speeches were made by foreign ministers and some of the delegates. In the evening an invitation performance at the Opera House, illustrative of Hungarian drama and national life, was followed by a reception given by the Minister of Education.

On Friday morning, September 27, the delegates of the University staff met under the central dome of the Parliament House to take part in the principal academic event of the celebrations. His Serene Highness, the Regent of the Kingdom of Hungary, their Royal Highnesses the Archduke Joseph and his son, the Archduke Francis Joseph, were present. The Rector Magnificus, Dr. Julius Kornis, opened the proceedings and, after other members of the University had spoken, a representative of the University of Bologna spoke on behalf of the foreign universities, and the foreign secretary of the Royal Society of London was asked to speak on behalf of the whole body of academies. The latter paid a special tribute to the memory of one of the greatest sons of Hungary, the founder of the Hungarian Academy, Count István Széchenyi, "a man whose enlightened attitude towards learning, breadth of vision and spiritual ideas are worthy of our most respectful and grateful homage". Delegates were then called upon to present their addresses : English, Scotch and Welsh universities were represented, universities of the Irish Free State, of Austria, Belgium, Egypt, Denmark, Latvia, France, Finland, Germany, Greece, Holland, Italy, Norway, Poland, Spain, Sweden, Switzerland, the United States of America, and other countries.

In the afternoon some of the delegates were present at the laying of the foundation stone of a now University hospital for lung diseases. Each medical professor has his own University hospital. An informal entertainment was given by students in the evening.

In the morning of September 28 a large number of honorary degrees were conferred. Unfortunately, the two English graduands, Sir Charles Sherrington and Sir F. Gowland Hopkins, were not able to receive their degrees in person.

In the afternoon the Regent received the delegates in the Royal Palace and talked with many of them with equal fluency in German, French and English. In the evening the visitors had the privilege of hearing Beethoven's "Missa Sollemnis" with an impressive accompaniment of a liturgical drama produced by the director of the National Theatre. 
The celebrations were admirably organised: the attractive Hungarian national uniform worn by the University officers, the brilliant robes of the cardinals, the white, brown and black vestments of members of monastic orders, and the variety and wealth of colour represented by the gowns and hoods of delegates contributed to the gaiety and splendour of a great occasion. The celebration was an important national event which made a very favourable impression upon the international company and created a feeling of sympathetic interest in the welfare of a courageous nation. Delegates who had the good fortune to be guests of the University in one of the most beautiful of European cities will long retain the pleasantest memories of the friendliness of the Rector Magnificus, the Ministers of State and the University officers with whom they came into contact.

\section{Educational Topics and Events}

CAmbridge.-The managers of the Balfour Fund have made a grant of $£ 100$ to F. R. Parrington, of Sidney Sussex College, for researches on the fish fauna of the Achenarass quarries.

It is proposed to confer the degrees of M.A. and M.D. honoris causa upon Dr. J. A. Ryle, regius professor of physic, and the degree of M.A. on Dr. G. P. McCullagh, University demonstrator in pathology.

LeEds.-Mr. Frank Stuart Atkinson has been appointed to the chair of mining, in succession to Prof. Ritson, who takes up his appointment at the Royal School of Mines at the beginning of January next. Mr. Atkinson is a qualified mining engineer. $\mathrm{He}$ was educated at Chesterfield Grammar School and the University of Sheffield, and has had a long and varied experience of practical work ; he has been manager of the Hatfield Main Colliery since February 1927.

London.-The title of Edwards professor of Egyptology in the University has been conferred on Mr. S. R. K. Glanville, in respect of the post held by him at University College.

The title of emeritus professor of bacteriology in the University has been conferred on Dr. J. W. H. Eyre, formerly University professor of bacteriology at Guy's Hospital Medical School; and that of emeritus professor of civil engineering in the University on Mr. A. H. Jameson, who has retired from the University chair of civil engineering at King's College.

OxroRD.-Dr. John Mellanby, professor of iphysiology in the University of London, has been appointed to the Waynflete professorship of physiology, to hold office from January 1, 1936.

The Council of the Institution of Naval Architects has made the following awards: 1851 Exhibition Commissioners post-graduate scholarship in naval architecture, $£ 250$ per annum for two years, to $\mathrm{Mr}$. Harrison Lackenby, of Armstrong College, Newcastleupon-Tyne; Sir William White post-graduate scholarship in naval architecture, $£ 150$ per annum for two years, to Mr. Ian C. Bridge, of the University of Glasgow; Earl of Durham Prize, to Mr. D. H. Burnett, of H.M. Dockyard, Devonport.

\section{Science News a Century Ago}

\section{Meeting of the Entomological Society}

Aт a meeting of the Entomological Society held on November 2 , 1835, the president, the Rev. F. W. Hope, being in the chair, several communications were read, one of which was a notice of the ravages of the black caterpillar upon the leaves of the turnip in Kent, by W. W. Saunders. "Relative to this com. munication Mr. Yarrell stated some additional circumstances regarding the destruction of the turnip last summer and autumn, by the insect in question, which were the larvæ of a species of Saw-fly (Ten. thredinidæ) termed by the farmers 'the blacks'. In the dry summer of 1818 these insects were equally destructive, and so rapid is the destruction caused by them, that in a couple of days a fine field of turnips is reduced to the mere skeleton of the leaves. Mr. Hope gave an account of some other insects which had this year been equally injurious to the turnip in Shropshire, Herefordshire and Worcestershire and suggested several plans for their destruction."

\section{Beginning of Faraday's Researches on Electrostatics}

"HAve been thinking much lately," wrote Faraday in his Diary on November 3, 1835, "of the relation of common and voltaic electricity; of induction by the former and decomposition by the latter, and am quite convinced that there must be the closest connexion. Will be first needful to make out the true character of ordinary electrical phenomena. The following notes are for experiment and consideration.

"Does common electricity reside upon the surface of a conductor," he went on, "or upon the surface of the electric in contact with it? I think upon the electric, and must work out the results on that view. It will make a great difference in the collation and connexion of the various electrical phenomena and also in their explication."

Then follow a dozen or so pages, written on the same day, of speculation on such points as the effect of the form of a conductor on its electrical behaviour, on the relation of two surfaces under induction, and on the state of the dielectric, or as he called it, the "electric", during the persistence of inductive action. Together with the queries are ideas and suggestions for experiments by which they may be tested.

This was the beginning of Faraday's researches on electrostatics. The work on electrochemistry had been completed early in the year, and very little had been done during the summer months. Now, in the autumn, he was ready to begin again, and the first step was to put down on paper the ideas for experiment that had come crowding to his mind ; next, in a few weeks time, he would be devising the necessary apparatus.

\section{New Session of the Geological Society}

ON November 4, 1835, the Geological Society held its first meeting of the session. A paper by Dr. Buckland was first read on the discovery of the beaks of four extinct species of fishes, referable to the genus Chimcera, and found in the Oolitic and Cretaceous series of England. The paper was accompanied by an appendix by M. Agassiz, describing the distinctive characters of each species.

A communication by Mr. Murchison was next read, containing an account of the quarry in the new red sandstone at Rhone Hill, near Dungannon, in which 